\title{
Research on training difficulties and breakthrough path of high skilled talents in China's manufacturing industry Li Weijuan
}

\author{
Shengli College China University of Petroleum, department of Chinese Law and Economics \\ Management,Dongying ,Shandong, China \\ Liweijuan666@163.com \\ *liweijuan
}

\begin{abstract}
Keywords: Integration of production and education, Manufacturing industry, Highly skilled talents, Personnel training.
\end{abstract}

\begin{abstract}
The goal of China's "manufacturing power" can not be realized without the support of high skilled personnel. There is a interaction relationship between them. Through the analysis of the current situation of high skilled personnel in China's manufacturing industry and the difficulties in training, three breakthrough paths are put forward in the view of the integration of production and education. It is to improve the Policy Resources of High-skilled Personnel in Manufacturing Industry from the Government Level, to strengthen the Correct Cognition of the Talent Training from the Enterprise Level, to dock the development demand of the New Era in the transformation and upgrading of Manufacturing Industry from the University Level. The aim is to provide the suitable high skilled personnel support for the development of the manufacturing industry.
\end{abstract}

\section{我国制造业高技能人才培养困境及突破路径研究 李伟娟 \\ 中国石油大学胜利学院文法与经济管理学院, 东营, 山东, 中国 liweijuan666@163.com \\ *李伟娟}

关键词：产教融合;制造业;高技能人才;人才培养

中文摘要. 我国 “制造强国” 目标的实现离不开高技能人才的支撑，两者存在相互作用关系， 通过分析我国制造业高技能人才的现状和培养中存在的困境, 结合产教融合视角提出三种突 破路径, 分别是从政府层面完善制造业高技能人才的政策资源, 从企业层面强化对人才培训 的正确认知, 从高校层面对接制造业转型升级中新时代发展需求, 目的在于为制造业的发展 提供合适的高技能人才支撑。

\section{1. 引言}

十九大报告明确提出要建设 “制造强国” 的目标, 在助推该目标实现的众多因素中, 制 造业的高技能人才必不可少。阳立高(2014)提出高技能人才是推动产业转型升级和经济增长 的重要力量 ${ }^{[1]}$ 。胡茂波 (2018) 通过测算得出高职技能型人力资本的贡献率显著 ${ }^{[2]}$ 。为此, 国 家出台多项政策支持高技能人才的培养，如《高技能人才队伍建设中长期规划(2010-2020年)》 提出的产业政策与高技能人才开发政策相互协调的原则; 《国家中长期人才发展规划纲要 
略目标; 另外作为目前人才培养中 “产教融合” 的方式也多次被提出, 该概念首次由《国务 院关于加快发展现代职业教育的决定》国发〈2014〕19号提出, 之后在《国务院办公厅关于 深化产教融合的若干意见》国办发 (2017) 95号中再次得到推广, 提出将教育链、人才链与 产业链进行有机协调。目前 “产教融合” 观念被重点用来破解产业和教育间不协调的矛盾 ${ }^{[3]}$ 。

\section{2. 我国制造业转型升级中对高技能人才需求的必要性分析}

作为我国国民经济的支柱产业，国家对制造业的发展不仅在政策上出台多项支持政策， 在资金上也是大力扶持。2017年制造业总投资193616亿元，占国家固定资产总投资的 $30.7 \%$, 国家投资力度逐年加大, 但与投入相比, 产出情况却出现下滑。在与高技术制造业增加值的 对比中，2017年全国制造业增加值增长率7.2\%，而高技术制造业增加值的增长率却增加 $13.4 \%$, 表明了高新技术对产值创造的重要性。同时, 全国制造业的就业人数逐年减少, 从2012 年的 23241 万人减少到 2016 年的 22350 万人, 下滑 $3.8 \%$, 表明目前人们在择业的过程中心理还 存有一定的错误认知。按照世界大都市的发展规律, 随着第二产业工业的转型升级, 技术集 约化和高端化是其未来的发展趋势 ${ }^{[4]}$ 。高素质劳动力需求上升, 高技能人才成为未来决胜的 关键。对于高技能人才的概念。每个国家的标准不同, 我国对高技能人才的概念主要参考《高 技能人才队伍建设中长期规划（2010-2020年）》中的规定, 指具有高超技艺和精湛技能, 能 够进行创造性劳动并对社会做出贡献的人, 主要包括技能劳动者中取得高级技工、技师和高 级技师职业资格的人员。类似西方职业带中的 “技术工人” 和 “技术员” 系列 ${ }^{[5]}$ 。余汶桦， 张毅芳（2018）结合OECD技能战略强调了国家、企业、教育机构和劳动者个人 4 个要素对技 能培养的影响[6]。

\section{3. 我国制造业高技能人才现状及培养中存在的困境}

\section{1 制造业高技能人才现状}

目前制造业的高技能就业人员严重不足且存在结构化矛盾。根据近年来我国劳动力市场 的人才需求显示, 高级技工的岗位数与求职人数之比高达 2 : 1 以上。但根据《中国劳动统计 年鉴2017》统计数据显示, 目前全国共有技工学校 2526 个, 劳动预备制度定点培训机构数 1298 个, 其中具有初级职业资格、中级职业资格、高级职业资格以及技师和高级技师资格的人数 分别为 1661537 人、466914人、 125034 人和 9617 人，技师以及高技能人才不足。另外制造业的 就业人员数量却出现下滑, 2016 年制造业城镇单位就业人员数量 4893.8 万人, 相比 2015 年减 少174.9万人。另外, 根据中国劳动科学研究所《2010-2020年我国技能劳动者需求预测研究报 告》, 未来我国技能型人力资本需求规模约为 11577.3 万人, 人力资本市场的供给缺口达到 927.4 万人。其中, 高技能、高素质人力资本需求为 3067.1 万人, 供给缺口达到 105.8 万人。众多统 计数据表明目前我国制造业在转型升级的发展中没有得到数量充足、技能结构合理的技能大 军的支持。

\section{2 制造业高技能人才培养中存在的困境}

（1）社会对技工岗位以及在制造业的工作心理认知不足，从业动力不强。一是以往制造 业从业人员的社会地位低, 收入偏低, 造成了广大家长和学生在选择受教育的过程中追求学 历不重视技能的现象。如2016年制造业城镇单位就业人员平均工资 59470 元, 低于城镇单位就 业人员67569元的平均工资, 在2016年的行业工资统计中, 平均工资最高的行业是信息传输、 计算机服务和软件业和金融业，城镇单位就业人员平均工资分别高达 122478 元和 117418 元， 劳动薪酬差异大, 导致制造业岗位在招聘中不具有竞争力。二是教育界长期 “重学历、轻技 术” 的教育体制, 使现代社会中很多大学生对高端制造业中的技能工作产生理解偏差, 认为 
“技能型人才” 不是高端人才, 不如白领的工作有面子, 不愿涉足此行业, 这严重限制了我 国高端制造业优秀人才的来源。

（2）企业对高技能人才的培训参与度不高，“只招不培” 的做法形成恶性循环。目前企 业 “只想用人, 不愿育人” 的观念依然在不少企业存在, 一方面, 不肯在员工职业技能培养 上多下功夫, 将人力培训看作成本投入, 担心培训后的员工跳槽、被挖墙脚等, 对员工缺少 职业规划, 激励措施不完善。另一方面, 过多依赖学校的培养, 经过短期的象征性培训直接 上岗, 导致新员工与工作的磨合时间增长, 受挫性加大。根据北京华恒智信人力资源顾问有 限公司的调查显示, 目前我国制造业员工教育费占企业年销售收入的平均比重不足 $2 \%$, 其中 $43.7 \%$ 的企业不足 $0.5 \%$, 只有 $4.6 \%$ 的培训投入在 $5 \%$ 以上。另外部分企业的培训形式过于单一, 形式化严重, 导致效果不理想, 员工离职率高, 只能不停的招聘新员工, 形成恶性循环。

(3) 高校的人才培养模式短时间难以改进，人才培育成果滞后。目前我国高技能人才的 培养要求主要集中在高职院校和部分应用技术型大学。目前仍存在较多问题, 部分学校的办 学理念没有完全适应市场经济的需要, 与企业结合力度不够, 培养定位不准确, 盲目追求科 研型高校的发展方案和专业设置, 培养特色不鲜明; 教学内容和人才培养模式等无法及时更 新, 传统教学为主, 无法对接新时代企业转型升级的需求, 导致毕业生的人才培养能力无法 对接新时代需求。如目前复合型技术营销人才成为热门抢手人才, 尤其是对大数据技术的应 用以及人工智能的要求加大, 但很多高校的专业设置并没有此专业。

(4) 由于传统观念束缚, 职业技能培训学校数量和培训时间都有待提升。根据《中国教 育统计年鉴2016》统计显示, 2016年, 全国中等职业教育共有学校1.09万所, 比2015年减少 309 所, 其中, 技工学校 2526 所, 比 2015 年减少 19 所。技工学校毕业生 93.07 万人, 比 2015 年 减少 1.55 万人。技工学校的专任教师 19.64 万人, 比去年增加 4807 人, 师生比有一定的增长, 表明国家开始从师资上重视技能人才的培养。2016年职业技术培训学校共2124所, 其中教育 部门、其他部门以及民办的学校 (机构) 数量分别为859所、867所和398所, 在按产业结构划 分的结业生人数中, 第二产业类的培训仅有 6664491 人, 而第一、三产业的培训分别为 16534102 人和 19151267 人, 第二产业工业的培训人数明显不足, 表明第二产业就业人员对培训的重视 程度不足。从培训时间上看, 以一个月以内的时间居多, 占到 26602068 人, 而 1 年及以上的受 培训人数仅有 955647 人, 培训时间太短无法保障培训的质量。

\section{4. 产教融合视角下制造业高技能人才培养的突破路径}

\section{1 政府层面}

（1）颁布相关政策认可职业技能的重要性，提升制造业高技能人才社会地位，纠正人们 对制造业行业和技能岗位的错误认知。产教融合要求加强产业与教育的融合, 这首先需求政 府层面的政策支持, 尤其在高技能人才培养过程中需要有学历和职业资格的双重评价, 国家 的 “政策资源” 支持必不可少, 将职业技能培养与高等学校的学术科研类同等重视将有利于 人们思想上的纠正。同时，国务院于 2018 年4月印发的《关于推行终身职业技能培训制度的意 见》, 明确提出加强员工的终身职业技能培训并加大了各项补贴资金, 这利于提高劳动者的 综合素质，结合时代发展及时更新技能，便于解决就业中的结构化矛盾。

（2）要积极引导企业参与到技能人才的培养中，对强调人才培养的重要性。因为只有企 业更清楚自身发展的瓶颈以及急需的人才标准，德国的员工有 $2 / 3$ 的人员都接受过其 “双元制” 的职业技能的培训, 确保员工的实践技能与其所学的理论相融合。建议企业间成立联合培养 机构, 根据制造业特有的行业发展规划, 制定高技能人才的培训规划, 由政府出面给予参与 的企业合适的激励政策; 同时积极推进职业技能培训市场化、多元化, 发挥社会各类力量共 同参与高技能人才的培训体系建设。 
(3) 提升制造业高技能人才的待遇, 缩小与高薪工作的差距, 激发更多人才投身制造业 的发展中。如德国的技工人才水平就高于其社会的平均水平, 从待遇上表明国家对该岗位的 重视。2018年3月中共中央办公厅、国务院办公厅印发《关于提高技术工人待遇的意见》，提 出要从政治、经济以及社会三大层面提高我国高技能领军人才的待遇, 这从物质层面和精神 层面给予高技术人才很大的认可，利于鼓励更多的优秀人才掌握高技能。

\section{2 企业层面}

企业的发展离不开人力资本的支撑，是人才的最终使用者和受益者，应当主动承担对高 技能人才的培养。目前制造业的就业人员受教育水平较低, 缺少高水平人才, 需要不断的接 受继续教育以适应时代的需求。一方面, 更新原有错误的人才观念, 将人力资源看作企业生 产过程中最重要的生产要素, 只有提高劳动力的职业技能和综合素质才有助于提高企业的核 心竞争力, 故企业应更新用人观念, 将高技能人才的培养工作纳人企业的人力资源的战略规 划中。另一方面, 及时结合时代需求对技术工人的技能进行再培训, 摒弃以往 “一个技术用 一辈子” 和 “直接让员工上手免培训” 的思想, 学习德国和日本的工匠精神, 通过在职培训 和脱产培训等方式鼓励在职员工接受培训, 为高技能人才定制职业规划, 为企业自身培养自 己的人才。

\section{3 学校层面}

(1) 调研制造业产业发展，完善课程体系，对接市场需求。制造业的高技能人才培养离 不开学校在专业上配套的课程设置。目前大多院校没有专门以制造业高技能作为培养的专业, 相近的专业如传统的机械设计、石油工程等专业。学校的人才培养应密切关注制造业产业转 型升级中对高技能人才的需求, 及时通过 “应届生求职网”、“中华英才网” 等人才招聘网 的招聘岗位需求以及到企业调研和专家研讨的方式总结制造业特有的职业技能和素质能力要 求, 以便有针对性的完善课程体系。如山东省高技能人才培养就经历了由 “传统岗位培养方 式一一到职业学校教育为主——再到校企合作培养 ”的发展历程。

（2）优化培养模式，丰富课程教学手段，有针对性培养制造业高技能型人才。一方面， 《国 家中长期教育改革和 发展规划纲要 (2010-2020年)》中明确提出, 要 积极依托 “三位一体” 的校企合作培养平台, 将教学活动与企业的生产紧密结合。强调了学 校的人才培养模式应结合社会与企业的需求, 从根据解决就业矛盾和技能型人才的结构矛盾。 院校可以结合自身情况以制造业的工作过程为主线, 建立基础知识与实践技能相对接的课程 目标, 形成 “双体系” 校企课程结构, 鼓励校企合作的人才培养模式, 多与企业共建实习实 训平台, 并将反馈意见纳入人才培养方案的修订中。另一方面丰富教学手段, 传统的教学以 理论教学为主, 结合板书和教材开展, 以讲授法和案例教学法居多, 还是以教师为主的教学, 学生被动接受为多。随着多媒体的应用, 现代教学中的电化教学越来越丰富, 可以仿真企业 生产情节, 以具体产品的工艺流程为导向, 加大情景教学, 锻炼学生解决实际问题的能力。

(3) 加大教师技能培训, 夯实教学基础, 对接新时代需求。高校教师的职业技能是学校 人才培养的基础, 制造业的转型升级对教师的职业技能提出了更高要求, 它的强弱与高技能 人才的培养质量息息相关。教师职业技能教育是顺应时代的要求, 要想培养的学生掌握企业 所需要的职业技能, 一方面, 教师就应及时掌握制造业的行业报告、产业动态、定期到相关 企业挂职进修, 了解制造业中对技能岗位的职业资格标准以及标杆企业入职岗位的要求, 培 养 “双师型” 教师。另一方面, 教师应借助新媒体等手段强化自身学习, 如在 MOOC 背景 下, 教师可以积极探索运用信息技术开发教师职业技能优质学习资源, 以深化教学内容。最 后, 鼓励有条件的高校招收有工作实践经历人员定期与在校教师进行交流, 尤其是针对部分 直接从高校毕业转变为教师角色的老师，因缺乏企业的实践经历，对真实的企业生产环节了 解不足, 通过定期沟通的方式掌握企业的真实需求。 


\section{5. 结束语}

随着制造业的产业转型升级, 行业竞争力由以往单纯的依赖资源和廉价劳动力转化为技 术创新, 高新技术制造业的增加值增速远高于制造业整体的速度, 高技能人才成为制造业未 来决胜的关键。但目前制造业的从业人员数量不足、结构化矛盾严重。由于受传统观念中 “重 学历轻技能” 的认知以及企业和高校在人才培养中的滞后和工作待遇中的不足导致制造业的 从业人员中高学历人才缺失, 高技能人才严重不足。为突破制造业高技能人才的培养困境需 要政府、企业和学校的共同努力, 从政府层面主要是完善政策资源给予政策保障, 确保高技 能人才的社会地位和薪酬待遇; 企业层面主要是转变人才培训的认知, 强化对员工的针对性 培训和职业规划, 从实践中提升高技能人才的培养, 形成企业自己的一套人才培养方案; 学 校层面主要是从学科群、教学手段以及师资上给予完善, 打牢必备的理论底子同时强化对制 造业的认知。“制造强国” 目标的实现需要多方的努力, 政府、企业以及高校的三方合作, 不仅利于国家 “制造强国” 战略目标的实现, 也有利于企业竞争力的提升和高校学生的就业, 进而实现多方的可持续发展。

\section{致谢}

本文为山东省本科高校教学改革研究课题《面向 “蓝黄战略” 的应用技术型人才培养模 式创新研究》（Z2016M096）; 山东省社会科学规划课题《数字经济助推山东半岛城市群装备 制造业核心能力提升研究》 (18CJJZ01); 山东省教育科学十三五规划课题《生态位视阈下黄 河三角洲高校服务区域经济与社会发展的实证研究》（YC2017098）的阶段性成果之一。

\section{References}

[1] Yang Ligao,Han Feng, Yang Huafeng and Liu Jianjiang,Experiences and Enlightenments of the Training of Foreign High Skilled Talents, Forum on Science and Technology in China, vol.7, pp. 121-126, 2014.

[2] Hu Maobo,Xie Lili and Yuan Fei,The Contribution Rate of Chinese Skilled Human Capital to Economic Growth and the Strategies for Upgrading-The Analysis Based on Statistical Data from 1995 to 2014, Vocational and Technical Education,vol.1, pp. 50-54,2018.

[3] YUAN Jingyu,Industry-University Integration in China: Historical Evolution and Ultima Strategic Choice, China Higher Education Research, vol.4, pp. 55-57, 2018.

[4] Zhou Wei,Analysis on the Law of World City Industry Development Journal of Commercial Economics, vol.10, pp. 107-109, 2012.

[5] Lu Wuxia ,Vocational Educational Difficulty and Its Breakthrough of Promoting HighlySkilled Personnel's Cultivation Specification-Connection perspective of higher vocational education and application-oriented undergraduate education, China Higher Education Research, vol.12, pp. 97-101, 2013.

[6] YU Wenhua and Zhang Yifang, Research on the Path of Skill Development in China from the Perspective of OECD Skills Strategy, Journal of Yangtze University(Social Sciences Edition), vol.3, pp. 86-89, 2018. 